\title{
In the Wake of the 2004 Great Indian Ocean Tsunami: Internally Displaced Persons and the Natural Disaster Response in the Maldives
}

\author{
Heather R. Croshaw \\ Environmental Law Institute and Adaptation Strategies International \\ PO Box 5379, Kingshill, USVI 00851, Virgin Islands
}

Tel: 1-609-744-2068Ｅ-mail: heather.croshaw@gmail.com

Received: January 10, 2017 Accepted: February 15, 2017 Published: February 28, 2017

doi:10.5296/jad.v3i1.10755 URL: http://dx.doi.org/10.5296/jad.v3i1.10755

\begin{abstract}
In the early morning hours on December 26, 2004, a magnitude 9.3 earthquake rocked the Indian Ocean, reaching the Republic of the Maldives approximately three and a half hours later. Thousands of Maldivians were displaced from their homes, with many having to leave their homes permanently. This article examines the response of the Government of the Maldives in the immediate aftermath of the 2004 tsunami and over the longer-term. Also, the article discusses the experiences of the internally displaced persons (IDPs) and the host communities, as well as the return migration of IDPs to permanent homes. Specifically, this article discusses the case study of the island of Kandholhudhoo, whose residents were temporarily relocated to eleven different atolls while Dhuvaafaru - their new home and a different island - was being constructed for permanent housing. The article examines best practices and difficulties with the response to natural disasters, managing IDPs, and the reconstruction process.
\end{abstract}

Keywords: Great Indian Ocean Tsunami, internally displaced persons, natural disaster response, natural disasters, tsunami, Maldives, return migration, post-disaster planning 


\section{Introduction - the aftermath of the 2004 Great Indian Ocean Earthquake}

In the early morning hours on December 26, 2004, a magnitude 9.3 earthquake rocked the Indian Ocean, with the epicenter located off the west coast of Sumatra Island, Indonesia (Papadopoulos, 233). The tsunami triggered by the earthquake raced both east and west of the epicenter. Approximately three and a half hours and $2500 \mathrm{~km}$ later, the first wave of the 2004 Great Indian Ocean Tsunami hit the Republic of the Maldives (Fritz et al, 137, 147). About one-third of the Maldives' population of roughly 300,000 was initially displaced by the tsunami (UNDP Tsunami Recovery). (Note 1)

This article aims to highlight the experiences of the Maldives during its post-tsunami response and reconstruction. (Note 2) The country faced unique circumstances due to its remoteness and challenges for rebuilding (or not rebuilding) entire islands and deciding whether to remove entire populations from "unsafe" islands. Finally, the article suggests action for going forward in the Maldives' natural disaster planning.

\section{The Tsunami, Natural Disaster, and Internally Displaced Persons}

Due to the remoteness of the islands and lack of early warning system, the Maldives had little to no advance notice of the approaching natural disaster - the early warning system was limited within the region (Siyah). (Note 3) Prior to the 2004 Tsunami, the Government of the Maldives (GoM or Government) had no national plan to deal with internally displaced persons (IDPs) and was very inexperienced with emergency planning (Brown, 48). The Maldives had not experienced a natural disaster of this magnitude or dealt with a violent conflict that would necessitate a plan for emergency services and IDPs. Thus, the GoM had to learn very quickly how to help and manage IDPs.

The Maldives is comprised of approximately 1,200 coral atolls encompassing an archipelago chain of 26 natural atolls. The country stretches $823 \mathrm{~km}$ north to south and $130 \mathrm{~km}$ east to west (Fritz, 137). The territory is spread over roughly $90,000 \mathrm{~km}^{2}$, but only $298 \mathrm{~km}^{2}$ is land, and the average ground-level elevation is 1.5 meters above sea level (Fritz et al, 138). It is the planet's lowest country in elevation and has the lowest natural highest point in the world at 2.4 meters. The country is divided into twenty administrative atolls. The capital island of Malé is very densely populated with approximately 104,000 persons living on $1.8 \mathrm{~km}^{2}$ of land (Fulu, 846). However, the rest of the country's population is highly dispersed; 70 percent of the inhabited islands have fewer than 1000 residents (Fulu, 846). (Note 4) Also, the islands have no natural bodies of water, and the soil is not well suited for complex agriculture, only simple crops (Fulu, 846).

Of all the countries struck by the Great Indian Ocean Tsunami, the Maldives had the highest percentage of its economy impacted by the natural disaster. The Maldivian economy relies primarily on tourism (74 percent), fishing (9.3 percent), and agriculture ( 3 percent) for its GDP (Fulu, 847). The scale of the damage in the Maldives affected 62 percent of GDP (US\$ 470 million), with the most effect on tourism, fisheries, and agriculture (Republic of the Maldives, One Year After, 13; UNDP Tsunami Recovery, 2). (Note 5) The tourism industry was impacted the hardest by the tsunami with direct losses of $\$ 100$ million, including up to 


\section{MInstitute Macrothink $_{\text {Ins }}$}

$\$ 55$ million in uninsured losses, and 10,440 jobs affected (Inderfurth, 18). (Note 6) In the agriculture sector alone, the tsunami wave and sea water damaged an estimated 1,200 farms and smallholder plots, as well as 840,000 timber trees (Williams, 22). Agriculture on the islands does provide many households with income, even though it is mainly a simple operation of selling fruits and vegetables to Malé (Fulu, 847).

The tsunami caused widespread destruction to the natural environment, infrastructure, and buildings, with the islands of the South Male Atoll hit the hardest (Keating and Helsley, 21). More than 100 islands lost key infrastructure, social, and health facilities, thereby making recovery very difficult (Brown, 48). (Note 7) Of the 198 islands, all but nine islands were either partially or completely flooded by the tsunami and fifty-six sustained major physical damage (Fulu, 849). (Note 8) Miraculously, the number of casualties remained low, especially compared to other countries impacted by the tsunami-approximately 108 people died or were reported missing (Papadopoulos, 238; Brown, 48), but more than 1,300 persons were injured (Fulu, 848). (Note 9)

The 2004 Tsunami is considered the worst natural disaster in Maldivian history (Fulu, 848). Somewhat surprisingly-due to its low elevation and vulnerable location in the Indian Ocean - the Maldives had not previously experienced a major natural disaster. The incident impacted the entire Maldivian population in some aspect, whether they were internally displaced, had property damage, experienced trauma and injuries, or lost their livelihoods. The extensive infrastructure damage limited the emergency relief services and the post-disaster reconstruction phase.

\subsection{The Government's Response - the Creation of the NDMC and MIDP}

Within one week, approximately 29,000 Maldivians had been internally displaced, and 8,000 houses were severely damaged or destroyed (Fritz et al, 139, and NDMC, Republic of the Maldives, One Year After, 13). (Note 10) Fourteen of the 199 inhabited islands were evacuated and several atolls were deemed uninhabitable (Brown, 48; Fulu, 849). The scale of the crisis was significant. The Government had to act quickly to adapt to the post-natural disaster situation.

At the time of the tsunami, the country had no plan or Government agency to deal with natural disasters and their aftermath, such as for assisting IDPs. (Note 11) Initially, the Ministry of Defense and its sub-agencies, such as the Coast Guard and the National Select Service, the Ministry of Planning, and the Ministry of Finance and Treasury handled much of the response after the tsunami, from communicating with remote islands to relocating people to distributing food and water provisions and managing the Tsunami Relief and Reconstruction Fund (Republic of the Maldives, One Year After, 10; A/HRC/19/54/Add.1, para. 27). (Note 12) By the end of the week, the GoM had established the National Disaster Monitoring Centre (NDMC) to handle the coordination of the relief efforts and all IDP-related services (Republic of the Maldives, One Year After, 12). (Note 13) The ad hoc agency operated out of a school, and at the time, was considered temporary (Hassan). Under the NDMC, the Managing Internally Displaced Persons Unit (MIDP) would coordinate and operate internally displaced persons programs (Republic of the Maldives, One Year After, 12). 
(Note 14)

The newly created agency faced a big challenge to assist IDPs effectively and quickly even with its limited capacity. The Government lost communication with some of the atolls for 3-4 days (Hassan). As a result, the NDMC was delayed in reaching some communities, which resulted in a fragmented response for the initial location and identification of IDPs (Siyah). Identifying the IDPs proved to be very challenging due to the extensive travel to all the islands and distinguishing an IDP from their host families (Hassan interview). Another contributing factor to the challenge of identifying IDPs was that many residents left their homes to move in with family members in other communities, to other islands, or relocated to Malé (Siyah). Many Maldivians found it difficult to locate some family members who had taken refuge with other families or friends or a host community, rather than in IDP housing. The process was extensive-it took about three to four years to register all the IDPs on the islands. Once identified by the MIDP, the IDPs were issued a green card for identification purposes (Hassan).

After one month, the construction of temporary IDP housing began, but even after six weeks, many residents still lived in tent camps, such as on Guraidhoo Atoll (Keating et al., 48 and 63). By mid-March 2005, the MIDP estimated that the number of IDPs was approximately 12,000 persons housed on 18 atolls. (Note 15) Many IDPs were initially housed in schools, where they received beds and fresh water (Siyah). Fortunately at the time of the tsunami, the schools were on holiday, so the NDMC could use the schools for temporary shelters until new ones were constructed (Hassan). (Note 16)

Temporary shelters were built on some of the islands, but not all of them, due to lack of resources, inhabitability, and remoteness. The IDPs were distributed across 18 atolls with $68 \%$ of the IDPs concentrated on four atolls: Raa (28\%), Laamu (15\%), Thaa (14\%), and Meemu (11\%). Additionally, 58\% of IDPs were displaced on islands other than their own, and $42 \%$ were displaced on their own islands (Republic of the Maldives, One Year After, 17). As of November 1, 2005, 46.3\% lived in transitional shelters, 35\% lived with others, $18.2 \%$ lived in damaged housing, and $0.5 \%$ lived in tents. With help from the international community, 725 apartments had been built that housed up to 11 people per unit (Republic of the Maldives, One Year After, 17).

One challenge that MIDP experienced was how to distribute housing to IDPs, due to the design of the shelter units, the materials used, and concern over how to divide families (Hassan). Some of the IDP housing units were temporary dormitory-style shelters that hosted several families in the same space. They often had to share sleeping areas and toilets, and had meals provided by a central kitchen, so there was not much privacy or homemaking (Brown, 48). The temporary housing built on the atolls of Meemu, Dhaalu, Thaa, Raa, and Laamu often slept up to 16 people per unit, thereby crowding several families together (Fulu, 850).

Based on feedback from IDPs, the MIDP changed the design and construction of IDP housing to three-room units, with one family to each room, and individual cooking and toilet facilities (Brown, 48). The planning process included community consultations and involvement of IDPs, who in turn established a taskforce to deal with all related IDP issues. However, 
women were often underrepresented in these meetings (Fulu, 858). (Note 17) Despite the participatory process for constructing IDP permanent housing being largely successful, some critics say the consultations delayed the construction of IDPs' permanent housing (Republic of the Maldives, One Year After, 17). The NDMC wanted to conform to international standards as much as possible, so the GoM consulted the Sphere standards when building the first temporary housing. (Note 18)

\subsection{IDPs and Host Community Perspectives - Tensions, Cooperation, and Planning}

The uprooting of many people from across different islands changed familial, social, and economic structures for IDPs. Many host families gladly accepted IDPs, but this policy was not a long-term solution (Brown, 48). Over time, the temporary housing situation faced difficulties. The host communities felt burdened due to shared housing and other resources, which resulted in some conflicts between IDPs and their hosts (Siyah). Further, the host families felt the pressure of IDPs living in their community and in their homes. IDPs were unhappy sharing facilities with each other - they wanted to be able to cook their own meals, and had concerns about violence towards women and children (Brown, 48). (Note 19) The overcrowding of IDP shelters caused tensions even within families due to the lack of privacy and space (A/HRC/13/20/Add.3, para. 46). Furthermore, the relocation of IDPs to new, expensive, high-quality housing exacerbated the conflict between the host communities and the IDPs, as the former were not eligible for such upgrades; thus, feeding the resentment and even causing more construction delays (A/HRC/13/20/Add.3, para. 29).

Also, the different island identities sometimes created social conflicts between and within IDP families and with their hosts. Some communities did not want to accept IDP housing, particularly if the IDPs were from a different island because of these strong island identities and safety concerns (Hassan). IDPs had anxiety about security issues in camps because so many people were crammed in tight quarters and came from different areas in the Maldives (Fulu, 860). Additionally, tensions between IDPs and their host communities arose due to the lack of information as to when the IDPs would be able to move from the temporary to permanent housing (Republic of the Maldives, One Year After, 17; Brown 49).

To help ease tensions between IDPs and their hosts, the community leaders had to be innovative. On Alif Dhaal Atoll, the Chief suggested building an additional room in the compounds of households hosting IDPs to relieve overcrowding in the short-term (Brown, 48). This additional room to the host family dwelling would provide a long-term benefit for the host (Brown, 48). Thus, the host families willing to host IDPs received recognition for the overcrowding problem, but also a positive outcome with the expansion of their home.

In some cases, the population of the IDPs outnumbered their host community, creating a different social and economic dynamic than pre-tsunami. For instance, Villifaru was an island that was severely damaged by the tsunami. The island of Thaa Buruni hosted the entire population from Villifaru, but the IDPs outnumbered the host community (Republic of the Maldives, One Year After, 17). Eventually, tensions arose between the residents of Villifaru and those from Buruni, because the IDPs would receive new facilities on their island while the host community would not (Siyah). Also, the Buruni Islanders insisted on having their 
own school because the host community school became crowded (Syiah).

Furthermore, post-tsunami efforts had to address mental health issues due to the trauma caused by the natural disaster. The tsunami was a natural disaster that touched every person on the islands in some way-no one was left unaffected. Many IDPs needed psychological support for trauma and adjustment (Brown, 49-50). The Psychosocial Support Unit (PSU) at the National Disaster Management Centre worked with IDPs and others who dealt with trauma from the tsunami (Brown, 50). Many Maldivians lost friends and family, as well as their homes, property, belongings, and livelihoods. The island residents experienced impact injuries, illness, phobias, trauma (i.e. flashbacks and loss of sleep), and many died (Keating et al., 23). People were traumatized by the tsunami and its aftermath (Keating et al., 40).

\section{Return Migration of IDPs - Government and IDP perspectives}

\subsection{The Government's Strategy - To Build Back Better (or not at all?)}

The NDMC had effectively concluded immediate relief efforts by the end of January 2005, and so the institution shifted its focus to medium-term recovery (Republic of the Maldives, One Year After, 13). The initial focus of programming had been on basic services, but after a period of time, the IDPs needed assistance with social and economic activities to transition back to a "normal" life. In March 2005, the Government published its National Recovery and Reconstruction Plan (NRRP), which established the Ministry of National Planning and National Development as the head of the reconstruction efforts. (Note 20) Interestingly, the plan was committed to community consultation in the long-term planning process, particularly for those communities who would have to relocate from their islands.

The reconstruction phase from the 2004 tsunami focused on rebuilding and improving the lives of the affected communities beyond their pre-tsunami state (UNDP Tsunami Recovery, 26). This policy included bettering livelihoods, improving infrastructure, enhancing capacity, and implementing pilot projects to develop new skills or value-added industries (UNDP Tsunami Recovery, 26). The International Federation of the Red Cross/Crescent provided the majority of financing, and the Internal Displacement Division of the Office of the Coordination of Humanitarian Affairs (OCHA) played an advisory role (Republic of the Maldives, One Year After, 17). (Note 21)

\section{2 (In)Voluntary Migration of IDPs as a Policy Response}

The GoM had been considering an island relocation program prior to the tsunami. In 1998, it released the Population and Development Consolidation Policy to encourage voluntary internal migration to reduce the number of inhabited islands (Brown, 49). Specifically, the GoM identified islands that were too remote or too vulnerable to natural disasters and urged citizens to move to higher, safer atolls (Williams, 51).

The tsunami presented the opportunity to accelerate this policy, because it was considered a pro-active, strategic response. The GoM faced the decision whether to rebuild remote islands that have been historically inhabited, but extremely vulnerable to water-related natural disasters, or whether to target reconstruction monies and efforts towards relocation of 
communities to islands with better services and environmental protection (Brown, 49). However, the issue of relocation was contentious - islands and inhabitants had different needs (Brown, 49). Priority was given to communities from islands with major housing damage, but relocation was also available by request to other small and vulnerable island populations (Brown, 49). Ultimately, the Government selected five islands to host relocated populations: R. Dhuvaafaru, A. Dh. Maamigili, Dh. Kudhuvadhoo, Th.Vilufushi, and L. Gan (NRRP). The beneficiaries of the relocation projects were populations from R. Kandholhudhoo, M. Madifushi, Th. Vilufushi, Th. Gaadhiffushi, L. Kalhaidhoo, and L. Mundoo (NRRP). Two islands were completely reconstructed: Villifaru, a resort island, and Dhuvaafaru, an uninhabited island that housed the population from Kandolhudhoo (Hassan).

\subsection{Case Study: Relocation of Kandholhudhoo and Planned IDP Community of Dhuvaafaru}

The tsunami waters completely overran some islands that were later deemed uninhabitable, such as Kandholhudhoo, one of the smaller islands in the northerly Raa Atoll (Talbot 2012). After the tsunami, all of the island's residents were forced to evacuate (Talbot 2012). The island had already suffered from increasing monsoonal rain and tidal waves (NRRP). The Government deemed the island unsafe due to the lack of a reef to protect the land, but then had to find a new place to relocate the population (NRRP; Talbot 2012). The relocation of the residents of Kandholhudhoo was a post-disaster development project that involved moving an entire island's population and dealing with issues stemming from IDPs and host communities.

For the next 5 years, the IDPs from Kandholhudhoo lived on four different islands until the GoM was able to relocate them to their new island. (Note 22) The NDMC chose Dhuvaafaru, located $16-18 \mathrm{~km}$ to the west, as a relocation site because it was in the same atoll and it had a reef surrounding the island (Simonelli 2016; Wong 2011). Before 2008, the island of Dhuvaafaru was uninhabited. The island was larger in landmass than Kandholhudhoo (44 $\mathrm{km}^{2}$ versus $9 \mathrm{~km}^{2}$, respectively) and had a reef to protect the shores (Simonelli; IFRC).

The Government planned the construction of the island before anyone from Kandholhudhoo relocated there, but did involve the residents through the Community Involvement Plan (Siyah; Wong 2011). (Note 23) The Red Cross/Red Crescent funded $\$ 30$ million to build over 600 preplanned housing units on Dhuvaafaru, as well as schools, health clinics, roads, water and sewage infrastructure, and an independent electricity system (Talbot 2012). Also, the IFRC helped construct an administrative complex, auditorium, sports complex, rainwater collection kits, road networks, and wastewater collection systems (IFRC 2013). After the completion of construction, it accepted residents in 2009 and finalized the relocation in 2010 (Siyah).

The relocation of the residents of Kandholhudhoo faced several challenges. The construction boom across the Maldives caused a construction delay in building houses and key facilities, due to the increase in demand and high prices for transport, building materials, and labor, as well as their scarcity (Siyah; UNDP Tsunami Recovery, 30; A/HRC/13/20/Add.3, para. 25). This problem was compounded at times by a lack of cooperation between the community and the partner organization (Siyah). Also, the community consultations, while crucial for inclusion in a relocation project, did contribute to the delay (IFRC 2013). 


\section{MInstitute Macrothink $_{\text {Int }}$}

The design of the new housing impacted a person's or families' day-to-day household operations, such as drying fish (Siyah). The homes were a uniform, three-bedroom design (IFRC 2013; Talbot 2012). Eventually, the residents adapted their new homes to suit their needs - adding additional rooms for shops or planting gardens (Talbot 2012). When building the structures, it was important to design the permanent housing and infrastructure so that residents could operate them easily and be able to fix any problems (Siyah).

Another problem facing the IDPs from Kandholhudhoo was that close familial ties were stretched (Talbot 2012). Prior to the tsunami, many families had close familial ties and lived in proximity of each other on Kandholhudhoo (Simonelli 2016) When they moved to Dhuvaafaru, some of these traditional family groups were separated and had to adjust to their new living arrangements (Talbot 2012). Also, as noted above, the island of Dhuvaafaru (44 $\left.\mathrm{km}^{2}\right)$ is much larger than Kandholhudhoo $\left(9 \mathrm{~km}^{2}\right)$. So, it would take families longer to see their relatives. Any IDP relocation project must also consider population growth - today Dhuvaafaru has approximately 5,000 people living on the island, with many houses containing more than one family (Simonelli 2016). The island is at capacity and faces overpopulation concerns.

The livelihoods of the Kandholhudhoo residents primarily included fishing and tourism. Fishing is the primary livelihood activity in Dhuvaafaru. Many fishermen often leave for a month at a time to find fish and sell their catch to other islands or in Malé (Simonelli, 2016). Men dominated the fishing industry, and the women stayed at home to maintain the household (Simonelli 2016). After a time, residents thought that the fishing was better off the coast of Kandholhudhoo versus Dhuvaafaru (Simonelli 2016) Now, they had to travel significantly farther to catch the same quantity of fish stocks (Simonelli 2016). This perception of "good fishing" shaped how the residents felt about their economic security in their new location (Simonelli 2016). Regarding tourism, only a handful of residents work in this industry because not many resorts are located in this atoll (Simonelli). The closest resort is approximately 35 minutes to the south by speedboat, and workers must reside in cramped quarters on the island due to the distance (Simonelli 2016). As a result of the distance and difficulty, very few residents work in the tourism industry and rely mostly on fishing for income.

Additionally, the lack of resources (i.e. money, transportation) prevented the residents from relocating before the tsunami. The population was unable to relocate themselves due to the lack of options (i.e. hiring a boat) and the lack of funds (i.e. having an asset base) (Simonelli 2016). (Note 24) Without GoM and donor assistance, the population of Kandholhudhoo would have had a very difficult time relocating to a higher and safer island after the tsunami. The external financing and political will made it possible to move the entire population of the island to their new home. Although the Government had been moving towards the safer island program, the tsunami aftermath made this policy a priority.

Environmental degradation of Kandholhudhoo played a role their relocation as well. Residents of Kandholhudhoo had contributed to the vulnerability of their island to the tsunami due to environmental degradation (Simonelli 2016). (Note 25) The island was 
overcome by a $2.5 \mathrm{~m}$ wave because the island had very little natural defenses left. The residents had dredged the coral reef for building materials and cut down inland trees and the mangrove swamps for timber (Simonelli, 2016).

Then, the residents had to deal with environmental degradation on their "new island" as well, due to poor development choices by the Government contractors. On Dhuvaafaru, the developers had removed many trees and vegetation on the island during the construction phase (Talbot 2012). After the IDPs from Kandholhudhoo arrived, the IFRC and residents began to plant trees, even calling it the "Green Island" project (Talbot 2012). The vegetation has returned. Overall, the planned relocation of the IDPs from Kandholhudhoo to Dhuvaafaru was considered a success. The process had its challenges, difficulties, and problems, but overall the island is flourishing.

Going forward, the case study of Dhuvaafaru highlights the need for post-disaster projects to consider how to protect and incorporate natural resources into disaster risk and reduction planning to help mitigate future natural disasters and prevent environmental degradation, particularly in societies that live in vulnerable areas and rely primarily on subsistence fishing and agriculture. In the case of the Maldives generally, this policy directive falls in line with the "Resilient Island" approach advocated by the Government (Simonelli 2016). (Note 26)

\subsection{Rebuilding IDPs' Livelihoods for the Long-Term}

The Government had to consider how to rebuild the Maldivian livelihoods over the long-term, transitioning away from the post-tsunami policy to a more permanent solution. Livelihoods of IDPs were severely impacted, especially of those working in the tourism, fishery, and agriculture sectors. Many residents and IDPs lost their entire livelihoods or had their incomes severely impacted by tsunami damage or relocation. Some of the new locations were not conducive to their livelihoods. As a result, some IDPs felt a lack of independence because they lost their livelihoods in the fishing, fish-processing, and tourism industries (Brown, 48). (Note 27)

Despite the challenges, the tourism industry did bounce back. As of 2008, the Government estimated that as many as 44 uninhabited islands were being developed into tourist resorts and some inhabited islands for guest houses (Simonelli 2016). Also, these islands would house at least ten more regional airports, improving transportation between the islands (Simonelli 2016). The growing tourism industry can provide the funding base on the macro-economic level to help fund projects that focus on livelihoods and resiliency to natural disasters (Simonelli 2016). Today, the Ministry of Tourism states that Maldives have 87 resorts in 9 atolls with a total of about 16,000 beds and contributed to 71.8 percent of GDP in 2014 (Ministry of Tourism; World Travel and Tourism Council).

Women, in particular, have faced challenges in regaining and diversifying their livelihoods. As an example, the Kandholhudhoo residents were relocated to the planned community on Dhuvaafaru Island, where the population was heavily dependent on fishing (Simonelli 2016). The fishing grounds were close to the island (Talbot 2012). Women from Kandholhudhoo had played an active role in the fish processing-drying and processing the catch brought in by 
their husbands (Simonelli 2016). After families were relocated to Dhuvaafaru, the men have to travel further away to fish, sometimes taking multiple days to return (Simonelli 2016). As a result, the opportunities for women to take part in the fish processing have not been the same as before the relocation (Talbot).

\subsection{Problems with IDP Return to Permanent Housing}

The return of IDPs took almost 10 years to complete. After four years, the number of IDPs living in temporary housing because of permanent displacement from the tsunami decreased to 5,071 out of the initial 8,327 individuals displaced by the tsunami (A/HRC/13/20/Add.3, para. 31). (Note 28) The number of IDPs reduced to 1,600 by 2011, even though it was seven years after the tsunami (A/HRC/19/54/Add.1, para. 47). By the end of 2014, some IDPs still remained in temporary housing, but by 2015 the last remaining IDPs were relocated to new housing (Hassan).

The IDPs had many incentives to relocate from temporary shelters into permanent housing. The new houses were better than their old ones (Hassan). (Note 29) On some of the islands, the facilities built (e.g., schools and hospitals) were much improved over the previous ones (Siyah). Eligible communities received allowances to relocate as well as to supplement their income (NRRP; Two Years After). (Note 30) Also, the GoM and its respective branches handling the post-tsunami reconstruction placed a high priority on community consultations, the hands-on approach, and the participatory process (Williams, 51). While it may have slowed the physical reconstruction on the islands, the community consultations enabled the population to participate in the rebuilding process. Also, the transition from a donor economy created problems with financing new housing. The housing projects primarily funded by donors and international organizations (Hassan). When the donor money ended, this lack of external capital resulted in funding issues for housing (Hassan).

On the other hand, the transition from IDPs to permanent residents also had several problems. Some of the delays with IDPs transitioning into permanent housing were due to issues with construction, as mentioned previously. Many of the delays were caused by the construction boom that raised prices of construction goods due to the high demand and difficulties in transport (A/HRC/13/520/Add.3, para. 25; Siyah). For example, in 2011, the IDPs on the island of Kolhufushi still numbered 450 out of 700 persons (A/HRC/19/54/Add.1, para. 47). They lived in temporary homes, still waiting for the construction of their permanent dwellings (A/HRC/19/54/Add.1, para. 47). Eventually, they were relocated, but the construction delays and price increases for building goods created significant problems for transitioning IDPs from temporary housing into permanent housing.

Also, access to free basic services created a disincentive to leave temporary housing. The IDP housing had free basic services, such as food, electricity, and running water that made the transition to being self-sufficient vey challenging (Hassan). Additionally, the host communities had reservations over the free services, because they did not receive any of these benefits (Hassan). The Ministry of Planning and Development did not involve IDPs in the needs assessment and medium- and long-term planning stages, which in turn contributed to the IDPs lack of engagement in managing their own issues in the temporary housing 
(A/HRC/19/54/Add.1, para. 45). The integration of the IDPs into permanent housing either within the host communities or on their previous islands was part of the Government planning, but the failure to consult the IDPs resulted in a lack of ownership in the reconstruction programs (A/HRC/19/54/Add.1, para. 45; Siyah). In the aftermath of the tsunami, these free services provided by the Government were very generous, but after several years they proved to be a disincentive for IDPs to leave the temporary housing. The Government had no timeline as to when these services would terminate, which added to the delay for IDPs transitioning into permanent residents and tensions between IDPs and their host communities (Hassan 2016).

Many of the delays were due to the Governments' and reconstruction-related entities' insufficient experience in dealing with the complexities of land, housing, and community affairs (A/HRC/19/54/Add.1, para. 47). For example, in 2011, the IDPs on the island of Kolhufushi still numbered 450 out of 700 persons (A/HRC/19/54/Add.1, para. 47). They lived in temporary homes, waiting for the construction of their permanent dwellings (A/HRC/19/54/Add.1, para. 47). Eventually, they were relocated, but the construction delays and price increases for building goods created significant problems for transitioning IDPs from temporary housing into permanent housing.

Some communities did not want IDP housing at all, which in turn created more delays and conflicts between the hosts and IDPs (A/HRC/19/54/Add.1, para. 47; Hassan). Furthermore, during IDP consultations, the IDP community had a difficult time agreeing whether to rebuild housing on their original plots of land or to concentrate the new permanent housing in certain areas to consolidate resources (A/HRC/19/54/Add.1, para. 47). Equity also played a role disagreements arose over issues such as providing the same housing to everyone, despite the size of the family or extended family; the value of the previous house or property that had been destroyed; or whether or not the person even owned a house or land (A/HRC/19/54/Add.1, para. 47; Hassan). However, the quality of the permanent housing was much improved over the temporary housing, as well as some residents' previous housing because of stricter building codes.

\subsection{The Need for Legal Reforms to Improve Governance}

Despite all the post-tsunami reconstruction, the Government had not reformed the legal system to enable the disaster recovery institutions and policies to be permanent. In 2006, the first draft of the Disaster Management Bill was presented to the Government. However, the bill would not be passed until September 2015, taking almost ten years to have the NDMC in place officially and have legal authority (Hassan). (Note 31) The agencies became legally operational in 2016 (IFRC 2016). The bill established the specific roles and duties of the different levels of government to coordinate disaster-related relief and post-disaster activities, and set forth a national disaster management plan (A/HRC/19/54/Add.1, para. 19). The NDMC had already been working on a National Emergency Operations Plan (NEOP) and a damage assessments toolkit for island communities, but the NEOP will eventually be merged with the National Disaster Management Plan (ADRC: Maldives). Furthermore, the law creates a National Disaster Management Council (NDMC), the National Disaster 
Management Authority, a National Disaster Steering Committee, and an Emergency Operations Center (Shaahunaz and Nizar, and ADRC:Maldives). The new law calls for mainstreaming of disaster management across central government ministries, as well as implementing provincial, atoll, and island-levels of government to decentralize decision-making and include more local voices (A/HRC/19/54/Add.1, para. 20). The Disaster Management Bill does not, however, provide a legal framework for IDPs or relocation of persons due to a natural disaster. (Note 32)

Other legal issues involve resolving property ownership post-tsunami. After the 2004 tsunami, many documents were lost or destroyed (Hassan). The Government had to determine how to register the new housing to its owners. For starters, it created a new registry within the Ministry of Housing and Infrastructure for registering housing and land (Hassan). (Note 33) Property in the Maldives is managed by the Land Office. The two most important elements to prove legal rights in property are the identities of the right holder and the physical boundaries of the property (Williams 13). Evidence can include tax receipts, ID cards, utility bills, and ration cards (Williams 13). Deeds and titles issued by the Government are the main instruments to prove ownership, but they can be easily washed away in a tsunami or destroyed/damaged by floodwaters as evidenced by the tsunami aftermath.

Furthermore, determining which person in the household would own the new housing became a contentious issue. Housing was issued to each family and owned by multiple people in the household to ensure equal ownership. This method was effective as long as the family stayed intact. Families had to decide whether to register the house in the However, if the heads of the household split, the issue arose as to who would remain in the housing (Hassan).

\subsection{Including IDPDs in Consultations for Post-Disaster Planning}

Despite government policies and efforts to conduct community consultations in the planning process, at times the discussions did not go far enough to address community concerns or include them in the decision-making process. Involving both IDP and host communities in the planning process would improve the rights of host and IDP communities (Republic of the Maldives, One Year After, 17). For the relocation of Kandholhudhoo residents, the consultation process with the communities proved to be difficult because they were distributed across four different islands (Talbot). However, they should have been involved more in the construction phase, and communication with them and their host communities should have been continuous (Talbot). The increased community consultations would enable a strong civil society, including the enhanced participation of women.

One of the reasons the post-tsunami response in the Maldives was effective is the strong civil society spread across the different islands. Community organizations had traditionally played a key role in providing services (Williams, 51). Island communities had proven resilient, independent, and cohesive in rebuilding houses and mosques on their islands, hosting IDPs, and distributing relief supplies (WB/ADB). The mutual trust between the Government and the residents of the Maldives enabled the confidence to mobilize resources and directly participate in the post-disaster response, as well as implement the community consultations. 
3.8 Resilient Communities to Prevent IDPs - Preparing for Climate Change and Future Natural Disasters

Prior to the tsunami, the GoM had understood the reality of climate change and the need to prepare for it. The Maldives, due to its geographic location, environment, and topography, will be vulnerable to the effects of climate change, particularly to rising sea levels and natural disasters related to changing rainfall patterns (Rolnik, 5). The Government culture enabled it to quickly and effectively respond to such a natural disaster, even though it had no previous national plan or agency to deal with this kind of crisis (Williams, 51). Its willingness to learn quickly and adapt to changing situations aided the post-tsunami response to be effective and mostly successful. The Government was committed to investing in resilience.

However, any post-disaster reconstruction and future development will have to consider changes in the environment, such as sea-level rise and changing rainfall patterns. Given the Maldives low-lying topography, the Government and any agency involved in reconstruction and development will have to consider temporality and adaptation in planning to improve resiliency (Simonelli, 2016). Responses for the immediate needs of IDPs post-natural disaster versus long-term development goals should include adaptation measures to climate change, such as building on higher ground due to sea level rise, protecting and restoring mangroves, and improving water catchment designs and cisterns (Brown, 48; Simonelli 2016). The Maldives will be facing stronger effects from sea level rise, storm surges, and heavier rainfall that cause severe flooding, so choosing a new location for vulnerable housing and infrastructure is critical. While there is an immediate need to rebuild quickly to house displaced persons, any post-disaster planning should consider these nature-related vulnerabilities of islands to natural disasters because they need to be addressed in both short-term and long-term planning to improve the resiliency of these projects. For instance, during the post-tsunami reconstruction, sometimes buildings were reconstructed right on the water without any consideration of storm surge and other water-related disasters (Hassan). Future disaster risk and reduction planning should incorporate environmental and natural disaster considerations.

\section{Conclusion - Building for the Future}

The 2004 tsunami impacted the Maldives greatly-economically, socially, and environmentally. Even though the Maldives had no natural disaster or IDP-related plan prior to the tsunami, the country received much praise for how it handled the crisis (Williams, 51). Today, there are no more IDPs living in temporary shelters, but it took approximately ten years to get them into permanent housing due to construction delays and disincentives to transition from IDP status (/HRC/19/54/Add.1, para. 45-46; Hassan email 20 January 2016). (Note 34) The initial post-disaster response by the Government was lauded for its speediness and effectiveness. Many policy and legal reforms occurred, even if not at the quickest pace. The planned relocation of residents from Kandholhudhoo to the newly-constructed island of Dhuvaafaru overall went smoothly and the community is thriving. While the Maldives were significantly damaged by the 2004 Great Indian Ocean Tsunami, the islands have taken steps to improve the post-disaster response, protect the rights of IDPs, and involve IDPs in the 
planning process.

\section{Acknowledgements}

The author would like to sincerely thank Mr. Hisan Hassan and Mr. Ahmed Siyah for their time to speak with me and for their perspectives and experiences during the post-tsunami response and reconstruction phases, as well as current events in the Maldives. Also, the author would like to sincerely thank Dr. Andrea Simonelli for sharing her research and field experiences in the Maldives.

This study was partly funded by the Mitsui \& Co., Ltd, Environmental Fund. Support was also provided by the Reconstruction Agency of the Japanese Government through the Hirono Town Government.

\section{References}

2005 Republic of the Maldives Tsunami: Impact and Recovery, Joint Needs Assessment, World Bank-Asian Development Bank- UN System. Retrieved 8 February, 2017 from http://siteresources.worldbank.org/INTMALDIVES/Resources/mv-na-full-02-14-05.pdf

Asian Disaster Reduction Center (ADRC), Maldives, http://www.adrc.asia/nationinformation.php? NationCode=462\&Lang=en\&NationNum=36.La wrence, S. et al. (2001). Persistence of Web References in Scientific Research. Computer, 34, 26-31. Retrieved from https://doi.org/10.1109/2.901164

Brown, H. (n.d.). Lost Innocence: the tsunami in the Maldives. FMR Tsunami - Maldives (pp. 48-50).

Fritz, H. M., Costas, E. S., \& Brian, G. M. (2006). Maldives Field Survey after the December 2004. Indian Ocean Tsunami, Earthquake Spectra, 22(S3), S137-S154. https://doi.org/10.1193/1.2201973

Fulu, E. (2007). Gender, Vulnerability, and the Experts: Responding to the Maldives Tsunami. Development and Change, 38(5), 843-864. https://doi.org/10.1111/j.1467-7660.2007.00436.x

Inderfurth, A. K. F., David, F., \& Stephen, C. (2005). The 2004 Indian Ocean Tsunami: Six Month Report, The Sigur Center Asia Papers, The Elliot School for International Affairs (The George Washington University). Retrieved from https://www2.gwu.edu/ sigur/assets/docs/scap/SCAP25-Tsunami2.pdf.

International Federation of the Red Cross and Red Crescent Societies (IFRC). Disaster Law Programme. Annual Report 2015 - Advance version. Retrieved from http://www.ifrc.org/PageFiles/125622/DLP\%202015\%20annual\%20narrative\%20report\%20( advance $\% 20$ version) $\% 2016 \% 20$ Feb.pdf

International Federation of the Red Cross and Red Crescent Societies (IFRC). Maldives: Rebirth of a Community. Retrieved Feb. 14, 2017 from http://www.ifrc.org/en/what-we-do/disaster-management/responding/ongoing-operations/indi an-ocean-tsunami3/affected-countries/maldives-rebirth-of-a-community/

International Federation of the Red Cross and Red Crescent Societies (IFRC). (2013). Stronger Together: The global Red Cross Red Crescent response to the 2004 Indian Ocean earthquake and tsunami. Retrieved from http://www.ifrc.org/PageFiles/135535/1255200- 
Stronger\%20Together-EN-HR.pdf.

International Federation of the Red Cross and Red Crescent Societies (IFRC) (2007). Community Participation Building in the Maldives. Retrieved from http://www.recoveryplatform.org/assets/publication/community_participation_in_rebuilding_ Maldives.pdf.

Keating, B., Charles, H., Zaha, W., \& Dale. D.-H. (2004). Indian Ocean Tsunami on the Maldives Islands, Initial Observations. Science of Tsumani Hazards, 23(2), 19-70.

Ministry of Planning and National Development (MPND)(2009). The Maldives: Two Years After the Tsunami. Retrieved from http://planning.gov.mv/nbs/wp-content/uploads/2015/09/ Maldives-Two-Years-after-the-Tsunami.pdf.

National Disaster Monitoring Center, Retrieved from http://ndmc.gov.mv/

Papadopoulos, G. A., Riccardo, C., Brian, M, Sypros, P., Vassilios, K., Anna, F., Katerina, O., \& Sotiris, V. (2006). The large tsunami of 26 December 2004: Field observations and eyewitnesses accounts from Sri Lanka, Maldives Is. and Thailand. Earth Planets Space, 58, 233-241. https://doi.org/10.1186/BF03353383

Pardasani, M. (2006). Tsunami reconstruction and redevelopment in the Maldives. Disaster Prevention and Management: An International Journal, 15(1), 79-91. Retrieved from https://doi.org/10.1108/09653560610654257

Peter, S. (2007). Maldives: Homeless three years on-Victims remember the tsunami.Retrieved from http://reliefweb.int/report/maldives/maldives-homeless-three-years-victims-remembertsunami

Republic of the Maldives, Ministry of Planning and National Development, National Disaster Monitoring Centre, The Maldives: One year after the Tsunami (2005) [NDMC, One Year After], Retrieved from http://ndmc.gov.mv/assets/Uploads/The-Maldives-One-yearafter-the-Tsunami.pdf

Republic of the Maldives, The Disaster Management Act 2006. Retrieved from http://www.ifrc.org/Docs/idrl/880EN.pdf

Republic of the Maldives. (2005). National Reconstruction and Reconstruction Plan: Programmes and Projects, Eds. Ministry of Planning and National Development. Retrieved from http://www.tsunamimaldives.mv/idocs/Publications/NRRP.pdf

Shaahunaz, F., \& Asima, N. (2015). Maldives to form Disaster Management Authority, Haveeru Online. Retrieved Dec. 27, 2015, from http://www.haveeru.com.mv/news/65136

Simonelli, A. C. (2016). Good Fishing in Rising Seas: Kandholhudhoo, Dhuvaafaru, and the Need for a Development-Based Migration Policy in the Maldives, Migration, Risk Management and Climate Change: Evidence and Policy Responses (Vol. 6 of the series Global Migration Issues, pp. 131-148). Springer International Ltd.

Talbot, J. (2012). Returning to Dhuvaafaru, eight years on from the Indian Ocean Tsunami, International Federation of Red Cross and Red Crescent. Retrieved from http://www.ifrc.org/en/news-and-media/news-stories/asia-pacific/maldives/hussain-alifulhu-a -brighter-future-in-dhuvaafaru-maldives/.

Thasneem, F. (2012). Maldives: National progress report on the implementation of the Hyogo 


\section{Ml Macrothink}

Framework

for

Action

(2011-2013).

2017, Vol. 3, No. 1

http://ndmc.gov.mv/assets/Uploads/HFA-Report-Maldives-2011-2013.pdf.

United Nations Development Program: Maldives, UNDP Tsunami Recovery: Efforts in the Maldives (2005-2008), Restoration of Livelihoods: Sharing experiences (2008). Retrieved from http://www.mv.undp.org/content/maldives/en/home/library/poverty/Report0.html.

United Nations, Human Rights Council. (2010). Report of the Special Rapporteur on adequate housing as a component of the right to an adequate standard of living, and on the right to non-discrimination in this context, Raquel Rolnik. Retrieved 11 January, 2010, from http://www2.ohchr.org/english/bodies/hrcouncil/docs/13session/A-HRC-13-20-Add3.pdf

United Nations, Human Rights Council. (2012). Report of the Special Repporteur on the human rights of internally displaced persons, Chaloka Beyani. Retrieved from http://www.ohchr.org/Documents/Issues/IDPersons/A.HRC.19.54.Add.1_en.pdf

Williams, S. (2006). Getting Back Home: Impact on Property Rights of the Indian Ocean Earthquake-Tsunami 2004. New Issues in Refugee Research, Working Paper No. 122, UNHCR.

Wong, Alexander. (2011). Comparative Relocation: Case Study and Analysis of Options for Threatened Island Nations, Working Paper: Columbia Law School, Center for Climate Change Law. Retrieved from http://columbiaclimatelaw.com/files/2016/09/Wong-2011-08-Comparative-Relocation.pdf

World Travel and Tourism Council (2015), Travel and Tourism: Economic Impact 2015 Maldives. Retrieved

from https://www.wttc.org/-/media/files/reports/economic\%20impact\%20research/countries\%2020 15/maldives2015.pdf

Dhuvaafaru bid corruption case under investigation, Haveeru Daily. Retrieved January 21, 2006, from http://www.haveeru.com.mv/news/8823

\section{Interviews}

In-Person Interview with Mr. Ahmed Siyah, United Nations Development Programme, September 19, 2015.

Phone Interview with Mr. Hisan Hassan, National Disaster Management Centre, January 25, 2016.

Sendai Framework for Disaster Risk Reduction 2015-2030, A/CONF.224/L.2 (7 Apr 2015).

Report of the United Nations Conference on Environment and Development, Rio de Janeiro, 3-14 June 1992, vol. I, Resolutions Adopted by the Conference (United Nations publication, Sales No. E.93.I.8 and corrigendum), resolution 1, annex 1.

\section{Notes}

Note 1. The total population in 2004 was 270,101 (Fritz, 138).

Note 2. This article incorporates government policy documents, reviews by international 
human rights observers, U.N. bodies, and international financial institutions as well as news clippings, initial post-disaster surveys, literature, and interviews from two Maldivians who were part of the response efforts. The views of the interviewees are their own perspectives and do not reflect the positions of their employers.

Note 3. For example, Kandholhudhoo Island had an approximately 15 minute warning of the approaching tsunami due to a phone call from Malé (Fritz et al, 151). A manager at a Cocoa Island resort said that they had not received any warning via the internet; thus they were unprepared when the tsunami arrived and were unable to warn other islands (Keating et al, $65)$.

Note 4. The Maldivian Government is divided into three administrative levels: the island, the atoll, and the national government (Fulu, 848).

Note 5. The country relies heavily on tourism and fishing rights for livelihoods and income.

Note 6. Half of the $\$ 100$ million losses in the tourism industry was insured (Id).

Note 7. Fonadhoo islet of Laamu Atoll experienced the most damage to buildings and 22 people died and 3 were reported missing (Papadopoulos, 241).

Note 8. The Tsunami struck the Maldives in three waves (Maldives: One Year, 7 and Papadopoulos, 238). The wave heights ranged from 1.4 meters to 3.3 meters, with the highest measurement on the ocean side of Fonadhoo islet of Laamu Atoll (Papadopoulos, 241). The maximum water level did not exceed 2 meters on the atoll side (Papadopoulos, 238). Fortunately, the tsunami waves impacted the islands during daylight hours, low tide, and experienced a relatively short wave height (Keating et al, 39).

Note 9. Around 90 percent of the casualties were from 4 atolls - Meemu, Dhaalu, Thaa, and Laamu (Fritz et al, 139).

Note 10. Some reports have indicated the number of IDPs was as high as 29,000 (NDMC, Republic of the Maldives, One Year After, 13).

Note 11. The President issued a National Decree establishing the National Disaster Monitoring Center (NDMC) following the tsunami.

Note 12. Also, the Government enacted a task force to hand out relief supplies and an inter-ministerial committee headed by the Ministry of Defense and National Security. Other international navies, non-Governmental organizations (NGOs), the private sector, and community groups also assisted with the recovery process (Brown, 48; Republic of the Maldives, One Year After, 10). The International Federation of the Red Cross played a key role in the immediate aftermath, and established a Red Crescent branch in the Maldives (Siyah interview).

Note 13. Eventually, the Government handed the NDMC the responsibility of disaster preparedness and risk reduction as well (ARDC).

Note 14. The National Economic Recovery Unit, under Ministry of Finance - Housing and Infrastructure Redevelopment Unit (HIRU), coordinated by the Ministry of Planning and National Development would also be a part of the reconstruction process, but the MIDP unit solely handled IDPs.

Note 15. The NDMC database had approximately 15,000 IDPs registered at one point (Hassan). 
Note 16. After 2 weeks, the schools were reopened, and IDPs had been moved to new locations. Around $37 \%$ of schools required some sort of repair and six schools were completely destroyed. However, all schools were able to re-open on time for the academic session (Inderfurth et al, 15).

Note 17. A team from the OCHA Inter-Agency Internal Displacement Division visited the Maldives to inspect the IDPs living conditions and relocation plans to ensure they met international standards, which they did (Fulu, 858).

Note 18. See the Sphere Handbook http://www.sphereproject.org/handbook/.

Note 19. The Ministry of Health and Family conducted a survey in 2006, which concluded that one in three women aged 15-49 years have experienced physical or sexual abuse, and one in six women had been sexually abused before the age of 15 (A/HRC/13/20/Add.3).

Note 20. See the National and Reconstruction Plan at http://www.tsunamimaldives.mv/idocs/Publications/NRRP.pdf.

Note 21. International donors and agencies mobilized $\$ 400$ million in aid (A/HRC/13/20/Add.3)

Note 22. Kandholhudhoo had a population of 3,664 in 2004 (Fritz et al, 151).

Note 23. The Community Involvement Plan involved establishing beneficiary selection criteria with local leaders; using visual aids to inform the IDPs of the planning process; organized site visits; informal visits and meetings; communicating guidelines through graphics; and establishing a telephone hotline (IFRC 2007).

Note 24. For example, the population could not sell their property on Kandholhudhoo to enable the purchase and construction of homes on other islands (Hassan).

Note 25. Kandholhudhoo was not the only island facing environmental degradation due to unsustainable development practices. For example, land reclamation projects dredged the sea around the island and brought sand to the surface to increase land mass to deal with overpopulation of islands. In turn, this would impact the coral reef and natural sea movements that would cause increased coastal erosion and decrease the islands' natural resilience to storms as well as harm the reef ecosystem. A/HRC/19/54/Add.1 para. 34.

Note 26. Previously, the "Resilient Islands" approach was called the Safer Island Development Program (SIDP) (Simonelli 2016). The goal of this program was for the Government to identify "safe" islands that had more desirable environments (i.e. geophysical attributes, proximity to other islands, etc.) (Simonelli 2016). Also, it aimed to further connect the islands and consolidate resources (Hassan).

Note 27. For example, the main livelihood on Villifaru was fisheries, but Buruni Island was not ideal for fishing activities (Siyah). Previously, the fishermen from Villifaru would process fish in their backyards, but in their new location they were now in apartments (Siyah). They needed a place to dry the fish, but there was not enough space in the IDP housing so the fishermen would return to Villifaru to dry fish (Siyah). This process added more time, money, effort, and an additional need to supervise the catch to ensure it would not be stolen (Siyah).

Note 28. Initially, one-third of the 270,000 population was displaced in the immediate aftermath of the tsunami, but the number of Maldivians residing in temporary shelters was much less. 


\section{Macrothink}

Journal of Asian Development

ISSN 2377-9594 2017, Vol. 3, No. 1

Note 29. For instance, the houses were environmentally friendly, had tin roofs versus coconut thatching, and were larger in size (Hassan).

Note 30. The population of Kandholhudhoo also received cash allowances (Joint Needs Assessment).

Note 31. The bill did undergo a final stage of review at the Attorney General's office (ADRC: Maldives).

Note 32. The Special Rapporteur on the human rights of internally displaced persons, Chaloka Beyani, urged the Maldivian government to include an IDP provision within the Disaster Management Bill that would ideally embrace international human rights norms and the Guiding Principles on Internal Displacement (A/HRC/19/54/Add.1, para. 21).

Note 33. The NDMC did not handle the registration process (Hassan).

Note 34. The last IDPs moved to permanent housing in 2015 (Hassan email, 20 January 2016).

\section{Copyright Disclaimer}

Copyright for this article is retained by the author(s), with first publication rights granted to the journal.

This is an open-access article distributed under the terms and conditions of the Creative Commons Attribution license (http://creativecommons.org/licenses/by/3.0/). 